\title{
A Legal Conundrum: The Law's Treatment of Women
}

\author{
Susan Nott ${ }^{\star}$
}

The term 'conundrum' signifies, according to its dictionary definition, a riddle or a complex question. The proposition considered in this article is that the law's treatment of women constitutes a legal conundrum since it raises numerous complex questions, in particular why, given the law's apparent desire to improve the situation of women, it has failed them so consistently. The issue is an important one since there are numerous groups within society - ethnic minorities, the disabled, the elderly and homosexuals - who regard themselves as the targets of discrimination. The law's lack of success in achieving equality for women may provide important lessons for other groups in society who wish to use the law as a means of securing equality.

\section{How has the law failed women?}

The proposition that the law has failed women is one which requires examination in greater detail. There are those who regard this negative attitude towards the law as misrepresenting real achievements and discouraging women from seeking a legal remedy when they are the object of discrimination. ${ }^{1}$ There is no denying that compared to their position one hundred and fifty years ago or even fifty years ago women have made considerable gains. There has been a pattern to that progress. The first stage is represented by women's struggle to gain access to those privileges enjoyed by men from which women were excluded, either because they were women or, alternatively, because they were married women. This culminated in a series of legislative successes: ${ }^{2}$ the Married Women's Property Acts 1870, 1882, which gave married women the freedom to acquire and dispose of property; ${ }^{3}$ the

* Senior Lecturer in Law, University of Liverpool.

1. M. Rubenstein, "Beyond the Whinge", 11 Oxford fo. of Legal Stud. (1991), p. 254.

2. These successes were achieved only after lengthy campaigns for change. As an alternative but unsuccessful strategy, a number of cases were brought involving claims by women that the use of gender-neutral terms, such as 'person', in the legislation regulating the right to vote and entry to higher education and the professions gave women access to those rights, although previously they had been enjoyed by men alone. An account of these co-called 'persons' cases is given in A. Sachs and J. H. Wilson, Sexism and the Law (O.U.P., 1978).

3. Before the passage of this legislation control of a married woman's property was in the hands of her husband. 
Sex Disqualification (Removal) Act 1919, which gave women access to public office, the professions and higher education; and the Representation of the People Act 1918 and the Equal Franchise Act 1928, which gave all women over the age of 21 the right to vote. The struggle for access continues to the present day with women's campaign to be admitted to the priesthood.

The second stage came with the realisation that legislation granting women access to what had previously been denied them did little to alter the status quo. To take a single example, although women obtained the right to enter the legal profession in 1919 by the "mid-fifties only two per cent of solicitors and 3.2 per cent of barristers were women". ${ }^{4}$ It was abundantly clear that legislation guaranteeing access, or perhaps more accurately formal equality, was no defence against discrimination on the grounds of a person's sex or their married status. This is not to suggest that these gains were worthless but rather that they failed to address the true causes of women's inequality. To quote one commentator:

"The campaign for the vote, for married women's property rights, for custody and so on, were politically important. The fact that history has shown that women's oppression is not simply a matter of equal rights under the law should not blind us to the importance of those early struggles." 5

The passage of the anti-discrimination legislation - namely the Equal Pay Act 1970 and the Sex Discrimination Act 1975 - represented an effort to eliminate discrimination on the grounds of sex or marital status and secure women equal pay. At the time, this legislation, with its condemnation of discrimination on the grounds of sex, seemed to offer the key to equal opportunities. This was despite the warning in the White Paper which preceded the legislation that, without the right social and economic conditions, there were limits to what the law could achieve. ${ }^{6}$ Under the terms of section 1(1) of the Sex Discrimination Act 1975 discrimination is said to occur in the following circumstances:

A person discriminates against a woman in any circumstances relevant for the purposes of any provision of this Act if -

(a) on the ground of her sex he treats her less favourably than he treats or would treat a man, or

(b) he applies to her a requirement or condition which he applies or would apply equally to a man but -

(i) which is such that the proportion of women who can comply with it is considerably smaller than the proportion of men who can comply vith it, and

4. The Report of the Hansard Society Commission on Women At The Top, 1990, p. 46.

5. C. Smart, Feminism and the Power of Law (Routledge, 1989), p. 139.

6. Equality for Women (H.M.S.O., 1974), Cmnd. 5724, para. 21. 
(ii) which he cannot show to be justifiable irrespective of the sex of the person to whom it is applied, and

(iii) which is to her detriment because she cannot comply with it.

This definition of discrimination applies also to the manner in which a man or a married person is treated. ${ }^{7}$ In respect of pay a woman can utilise the Equal Pay Act 1970 to demand the same rate of pay as a higher paid male colleague in the same employment if that woman is engaged on like work, or work rated as equivalent under a job evaluation scheme or work of equal value. ${ }^{8}$ The employer can defeat her claim if he can establish that the woman's lower rate of pay is genuinely due to a material factor which is not the difference in sex.

There is no denying that the existence of the anti-discrimination legislation has proved beneficial to some women. Any likely benefit has undoubtedly been enhanced by the United Kingdom's membership of the European Community. The promotion of equal opportunities and equal pay are important aspects of Community policy. Article 119 of the Treaty of Rome provides that:

"Each member state shall ... maintain the application of the principle that men and women should receive equal pay for equal work."

In addition the Community has approved various directives to promote equal opportunities such as the Equal Treatment Directive ${ }^{9}$ and the Equal Pay Directive. ${ }^{10}$ The reason for the Community's insistence on equal pay and equal treatment is that without it those states that continued to pay women less than men would represent unfair competition to states where men and women were guaranteed equal treatment.

The strength of the European Community's commitment to equal opportunities is particularly apparent from the jurisprudence of the European Court of Justice. Its interpretation of Community directives and Treaty articles is based on a purposive rather than a literal approach. The desire to seek out the intention behind the legislation can prove very helpful to women. In the Dekker case, ${ }^{11}$ for example, the European Court stated categorically that a refusal to employ a woman because she was pregnant and would not be covered by an insurance scheme amounted to direct discrimination. Since only a woman can become

7. Sections 2 and 3, Sex Discrimination Act 1975. Discrimination against those who are married is relevant only in the context of employment. For an account of how the courts have defined and interpreted direct and indirect discrimination see A. E. Morris and S. M. Nott, Working Women and the Law (Routledge, 1991), Chapter 5; E. Ellis, Sex Discrimination Law (Gower, 1988).

8. Section 1, Equal Pay Act 1970. For an account of how the courts have chosen to interpret this section see Morris and Nott, supra n. 7, Chapter 6.

9. Directive $76 / 207$.

10. Directive $75 / 117$.

11. Dekker v. Stichting Vormingscentrum voor Volwassenen (VIV - Centrum) [1991] I.R.L.R. 27. 
pregnant the unassailable consequence of this was that a refusal to employ her represented direct discrimination on the grounds of sex. This contrasts sharply with the United Kingdom courts' treatment of claims that a dismissal on the grounds of pregnancy constitutes direct discrimination. Such claims have, in the main, been rejected unless the claimant can show that a man would not be treated in this manner. Since men cannot become pregnant this necessitates considering how a man suffering from some illness would be treated. ${ }^{12}$ The courts' contrived approach to pregnancy dismissal cases is attributable to their literal application of the Sex Discrimination Act when it calls for a comparison to be made between a woman and a man in comparable circumstances. ${ }^{13}$

Women in the United Kingdom have, however, been able to take advantage of the Community's greater commitment to equal opportunities. There have been occasions when the United Kingdom has chosen to implement Community legislation that gives women greater protection against discrimination. ${ }^{14}$ If the United Kingdom has not ensured that its law is in accordance with Community law then it seems that the English courts are now under an obligation to interpret their domestic legislation in a manner that is consistent with Community law. ${ }^{15}$ This is irrespective of whether the legislation in question was intended to implement Community law. ${ }^{16}$

There is a third and final stage to the process whereby women have attempted to use the law to achieve equal opportunities. This has required a reassessment of laws that ostensibly are designed to give women special protection. That special protection is usually said to be inspired either by the wish to safeguard a woman's fertility or to acknowledge her family responsibilities. In the past, for example, women had their hours of work restricted in recognition, so it was said, of their role as mothers. ${ }^{17}$ Employing the law in this fashion provokes the reaction that it

12. See, e.g., Hayes v. Malleable Working Men's Club [1985] I.R.L.R. 367. In Webb v. EMO (Air Cargo) Ltd. [1992] I.R.L.R. 116, the Court of Appeal affirmed once again that English law required a comparison to be made not simply between a woman and a man but between a woman and a man in comparable circumstances. In the case of a woman who was pregnant this entailed asking how a man in similar circumstances, that is suffering from an illness, would be treated. The European Court's decision in Dekker was distinguished on the basis that it concerned a decision not to recruit a pregnant woman, whereas in $W e b b$ the pregnant employee was incapable of performing the job for which she had been hired. See now the House of Lords' decision in Webb [1993] I.R.L.R. 27.

13. Sections 1(1)(a), 5(3), Sex Discrimination Act 1975.

14. See, e.g., Social Security Act 1989 which implemented Directive $86 / 375$. As a consequence the concepts of direct and indirect discrimination became applicable to occupational pension schemes and the Sex Discrimination Act 1975, section 6(4) was amended to take account of this.

15. Marleasing SA v. La Comercial Internacional de Alimentacion C 106/89, 13 November 1990.

16. According to the English courts, if legislation was not intended to implement Community law then they were under no obligation to interpret that legislation so as to take account of Community law: Duke v. Reliance Systems [1988] I.R.L.R. 118.

17. The Factory Act 1848 limited women's working hours to ten a day as well as forbidding night-time working. Restrictions on the hours women might work were finally repealed in the Sex Discrimination Act 1986, section 7. The true motives behind legislation of this nature are hard to discern. Such measures may have been intended to prevent women from competing with men for employment or to reassert women's primary role as caring for the family. 
condones discrimination since no account is taken of the needs of individual women. If the law sees fit to grant women special protection, and there are circumstances such as pregnancy when this is essential if women are to compete on equal terms with men, then it needs to be specific. The Employment Protection (Consolidation) Act 1978 and the Social Security Act 1986 do this very thing by granting a pregnant employee four specific rights: the right not to be unfairly dismissed because of pregnancy; the right to paid time off for ante-natal care; the right to Statutory Maternity Pay; and the employee's right to return to her job after the birth of her child. ${ }^{18}$ In contrast, other special protection measures exist which are regarded with much greater ambivalence. Section 51 of the Sex Discrimination Act 1975 renders lawful discrimination in employment which is necessary to comply with laws passed prior to the Sex Discrimination Act, for example the Health and Safety at Work Act 1974, where the discrimination is aimed at protecting women in relation to pregnancy, maternity or other risks specifically affecting women. ${ }^{19}$ Under the terms of section 51 an employer may attempt to exclude a woman from certain types of work using the excuse that this is necessary to safeguard her fertility, whatever her views on the matter might be. The special protection on this occasion would be no more than an excuse for discrimination..$^{20}$

One positive feature, so it is said, of women's campaign for equality is a growing awareness on the part of those responsible for the application and interpretation of the law of the purpose behind the equal opportunities legislation.

As Rubenstein has remarked:

\begin{abstract}
"The generation of judges which heard the first discrimination cases tended to regard the laws as infringements on the liberty of the subject and therefore to be interpreted restrictively. The new generation is much more prepared to accept that they are reforming statutes and therefore to be interpreted purposively. The older generation tended to view discrimination as an aberration from traditional English standards of 'fair play'. The new generation, if not quite prepared to accept that discrimination is
\end{abstract}

18. Sections 31A, 45 and 60, Employment Protection (Consolidation) Act 1978 and section 46, Social Security Act 1986. For a full account of the manner in which the law regards pregnancy see Morris and Nott, "The Legal Response to Pregnancy", 12 Legal Studies (1992), p. 54. The Trade Union Reform and Employment Rights Bill will, when it becomes law, add to this protection.

19. The original wording of section 51 was amended by the Employment Act 1989 so as to take account of the European Court's decision in Johnston v. The Chief Constable of the Royal Ulster Constabulary [1986] I.R.L.R. 263.

20. In Page v. Freight Hire (Tanker Haulage) Ltd. [1981] I.C.R. 299 an employer who did just this was held to have a defence under the unamended terms of section 51 . His discriminatory action was necessary in order to comply with a statute, the Health and Safety at Work Act 1974, which predated the Sex Discrimination Act 1975. If a similar situation were to arise today it is not clear whether the same decision would be reached or whether the English courts would insist on an employer demonstrating that he had no alternative to excluding the woman in question, which was the European Court's approach in fohnson (see n. 17). 
'institutional', would seem to recognize that it is widespread, yet difficult to prove." 21

Decisions such as those of the House of Lords in Pickstone v. Freemans ${ }^{22}$ and Fames v. Eastleigh Borough Councili23 are cited as instances of this enlightened approach which emphasises the purpose behind the anti-discrimination legislation and owes much to the example set by the European Court of Justice. In other contexts, however, the judiciary can still be found expressing stereotypical views of women. Rape is one such example where a woman's behaviour may be condemned as somehow 'causing' the rape. ${ }^{24}$

The positive benefits that changes to the law, a more sympathetic judicial attitude and membership of the European Community have brought women are undeniable. Indeed, greater awareness of women's needs has extended beyond the application of the anti-discrimination legislation. From the seventeenth century onwards the accepted view was that a husband could not be found guilty of raping his wife.

To Sir Matthew Hale: “. . . the husband cannot be guilty of a rape committed by himself upon his lawful wife, for by their mutual matrimonial consent and contract the wife hath given herself up in this kind unto her husband which she cannot retract." 25

Over the years exceptions were developed to this general principle, though in the main the principle remained intact. Yet the House of Lords' decision in $R$. v. $R$. has put an end to this immunity previously enjoyed by husbands. ${ }^{26}$ The reason for this was that such a state of affairs no longer accorded with the modern status of women.

To Lord Keith: "The common law is, however, capable of evolving in the light of changing social, economic and cultural developments. Hale's proposition reflected the state of affairs in these respects at the time it was enunciated. Since then the status of women, and particularly of married women, has changed out of all recognition in various ways which are very familiar and upon which it is unnecessary to go into detail. Apart from property matters and the availability of matrimonial remedies, one of the most important changes is that marriage is in modern times regarded as a partnership of equals, and no longer one in which the wife must be the subservient chattel of the husband. Hale's proposition involves that by marriage a wife gives her irrevocable consent to sexual intercourse with her husband under all circumstances and irrespective of the state of her health or how

21. Rubenstein, supra n. 1, p. 257.

22. [1988] I.R.L.R. 357.

23. [1990] I.R.L.R. 288.

24. Smart, supra n. 5, Chapter 2.

25. Sir Matthew Hale, History of the Pleas of the Crown, 1 Hale P.C. (1736) 629, quoted by Lord Keith in $R$. v. $R$. [1991] 4 All E.R. 481 , p. 483.

26. [1991] 4 All E.R. 481. 
she happens to be feeling at the time. In modern times any reasonable person must regard that conception as quite unacceptable."27

In view of these constructive features of the law's treatment of women it would seem difficult to sustain the assertion made in the opening paragraphs of this article that the law has failed women. There is, however, clear evidence that women are not benefiting as one might expect from the anti-discrimination legislation and it is impossible to dismiss this claim as feminist carping. The annual statistical reports prepared by the Equal Opportunities Commission (EOC) in order to compare the situation of working men and women in Britain provide many illustrations of the law's failure. The EOC's report for 1991 showed that in 1990 women who worked full-time earned on average 77 per cent of the hourly earnings of male full-timers. ${ }^{28}$ There was an even wider difference between the sexes when weekly earnings were compared. Though these figures are disappointing they represent an improvement as compared with previous years. As the EOC's statistical survey shows there are many reasons for these variations, one of the principle ones being job segregation. Women predominate in certain sectors of industry and certain occupations. For example, women's employment is concentrated in the service sector of industry as opposed to the manufacturing sector. Within the service sector women are most frequently found in certain occupations such as medical and other health services. ${ }^{29}$ It would appear that where women employees are in the majority then low pay is the order of the day. Men also seem better able to supplement their basic earnings with additional payments such as overtime payments or shift bonuses. The EOC quotes the example of electrical and electronic engineering where male manual workers derive 26 per cent of their total pay from additional payments but female manual workers derived only 17 per cent from the same source. ${ }^{30}$

A study undertaken by Industrial Relations Services entitled $P$ ay and Gender in Britain sheds further light on the differences in pay between men and women. ${ }^{31}$ The study uncovered a number of potential sources of pay inequality. Pay structures tended to be segregated by gender so it was not uncommon to find one pay structure for management which was dominated by men and another for clerical staff which was dominated by women. Grading structures covering mostly women tended to be shorter and when women were in the majority a pay structure was less likely to provide for additional payments. Indeed, the authors of the study concluded that the equal pay legislation, and in particular the notion of equal value, had a limited impact on pay restructuring. Tradition was far more likely to be quoted as the reason for organising pay structures in a particular fashion. ${ }^{32}$

27. Ibid., pp. 483-484 (Lord Keith).

28. Women and Men in Britain 1991, Equal Opportunities Commission, pp. 1-7.

29. Ibid., pp. 9-20.

30. Ibid., p. 7.

31. Pay and Gender in Britain, a research report for the Equal Opportunities Commission from Industrial Relations Services, 1991.

32. Ibid., Chapter 6. 
The EOC in its 1991 report also draws attention to the large numbers of women who work part-time. In 1989 forty three per cent of female but only eight per cent of male employees worked part-time. ${ }^{33}$ Part-time employees always seem to be at a disadvantage when compared with full-time workers. To quote the EOC:

"Women who work part-time continue to receive lower average hourly earnings than their full-time equivalents; indeed, the difference between the average hourly pay of full-timers and part-timers has actually widened over the past decade." ${ }^{34}$

The reason why so many women work part-time as compared with so few men is linked to whether or not a woman is married, whether she has dependent children and the age of her children. ${ }^{35}$ Such factors do not in general affect the economic activity rates of men. This emphasises that, whatever the anti-discrimination legislation may have achieved, it has not led to a more equitable division of the burden of childcare between men and women. Opportunities to work part-time are often to be found in low paid occupations. According to the EOC the figures for 1989 show that " 52 per cent of all female part-time employees worked either in selling (the lowest paid of the non-manual occupations) or in catering, cleaning and related occupations (one of the lowest paid of the manual occupations). This compared to only 16 per cent of their full-time equivalents." 36

Women's lower earning capacity as compared with men and the likelihood that during their working lives they may experience periods of economic inactivity or part-time work have other more indirect effects. One of the most significant is the consequence it may have on women's ability to provide for their old age and retirement. The figures show that in 1989 " 61 per cent of male and 37 per cent of female employees were in pension schemes." 37 Part of the explanation for this difference between the sexes is related to the number of female part-time employees. Few part-time employees, according to the EOC, are members of occupational pension schemes.

The Equal Opportunities Commission is not the only source of evidence that women have not derived the advantages one might expect from the antidiscrimination legislation. The Hansard Society established a Commission to consider the problems facing women wishing to gain access to senior positions in public, corporate and professional life. Their report, Women at the Top, ${ }^{38}$ highlights that women are still very much in a minority in these influential positions. Although, for example, increasing numbers of women are now entering

33. Women and Men in Britain 1991, Equal Opportunities Commission, p. 11.

34. Ibid., p. 1.

35. Ibid., p. 23.

36. Ibid., p. 27

37. Ibid., p. 33.

38. The Report of the Hansard Society Commission on Women At The Top, 1990. 
the legal profession, a considerable number will leave in mid-career in order to raise families. These women may return to practise as barristers or solicitors but their absence wil have caused them loss of seniority and consequently make their promotion to partnerships or Head of Chambers less likely. Women are also in a minority in the judiciary. Since judicial appointments are made from senior members of the legal profession and far fewer women than men will have the necessary seniority this produces a pool of candidates for the judiciary heavily dominated by men. ${ }^{39}$

Besides drawing attention to the lack of women in senior positions, the Hansard Society identifies what it sees as the barriers to equality. They are outmoded attitudes about the role of women, direct and indirect discrimination, the absence of proper childcare provision and inflexible structures for work and careers. ${ }^{40}$ Indeed they state categorically that discrimination against women is still widespread. This discrimination is not the unsubtle 'we will not employ women kind'. It consists instead of unspoken assumptions that are made about women, the existence of networks that exclude women, such as membership of the Freemasons, and the insistence that job applicants possess certain qualities such as youth or geographical mobility. Other research studies have also underlined the subtle and complex nature of discrimination which the legislation seems completely powerless to tackle. In Managing To Discriminate, ${ }^{41}$ a detailed study was undertaken of the recruitment practices of various private companies in a number of industries. What emerged from this study was "that informality in the channels, criteria and procedures of recruitment was both a common practice ... and one that facilitated the reproduction of job segregation." 42 Indeed the authors of this study were forced to conclude that "despite anti-discrimination legislation in the mid-1970s, a substantial number of employers, many of whom publicly subscribe to equal opportunities, are still 'managing to discriminate' on the grounds of sex through a variety of recruitment practices." 43

Apart from this overwhelming evidence of discriminatory practices continuing unabated it appears that those women who try to make use of the antidiscrimination legislation face an uphill task..$^{44}$ Research undertaken into the experiences of women bringing sex discrimination and equal pay claims has pinpointed the difficulties that women may encounter. They comprise the problem of securing good quality advice and representation before the tribunal, of withstanding the stresses, including victimisation, of bringing a claim and of

39. Ibid., p. 44.

40. Ibid., p. 2.

41. D. L. Collinson, D. Knights, M. Collinson, Managing to Discriminate (Routledge, 1990).

42. Ibid., p. 193.

43. Ibid., p. 192.

44. See, e.g., A. Leonard, fudging Inequality: The Effectiveness of the Industrial Tribunal System in Sex . Discrimination and Equal Pay Cases (Cobden Trust, 1987); A. Leonard, Pyrrhic Victories: Winning Sex Discrimination and Equal Pay Cases in the Industrial Tribunals 1980-84 (H.M.S.O., 1987); J. Gregory, Trial by Ordeal (H.M.S.O., 1989); Morris and Nott, supra n. 7, Chapter 8. 
facing the prospect that, even if she is successful, a woman may secure little in the way of compensation. There is also evidence that the members of industrial tribunals often show incomprehension or ignorance of the anti-discrimination legislation..$^{45}$

\section{Why has the law failed women?}

There appears to be incontrovertible proof that for all its promise the antidiscrimination legislation is failing women. It remains to be seen why this is so. One obvious explanation is that the anti-discrimination legislation has not succeeded in its aim of promoting equal opportunities. Part of the problem may be that the concept of equality championed in the legislation does not accord with women's needs and aspirations. The Sex Discrimination Act identifies two forms of discrimination - direct and indirect. Direct discrimination occurs when a woman is treated less favourably on the grounds of her sex than a man. Indirect discrimination takes place when a condition is applied to both sexes but the proportion of women who can comply with it is considerably smaller than the proportion of men and as a consequence a woman suffers a detriment because of her inability to comply. In the case of indirect discrimination it is a defence to show that the condition in question is justifiable irrespective of sex.

Direct discrimination requires that men and women be treated in the same fashion. The problem with this approach is that it totally ignores the differences between men and women. Apart from the obvious biological differences, there are the differences that arise from the fact that women are expected to assume and do assume the major responsibility for childcare. This fact has an obvious and adverse effect on women's economic prospects. Therefore, the hypothesis that if a woman is treated in the same manner as a man would be she has achieved equality, is patently untrue. In order to benefit from the current definition of direct discrimination a woman has to be able to adopt a lifestyle that approximates to that of a man. The lack of practical impact of the legislation comprehensively demonstrates the inability of the majority of women to do this. The concept of indirect discrimination does admittedly offer an opportunity for challenging what appears to be even-handed treatment to assess its true effect on women. Women can argue that a seemingly neutral requirement works to their disadvantage because of the inability of a sizeable number of them to comply with it. The scope that indirect discrimination affords for challenging institutionalised discrimination has been undermined in the United Kingdom by the manner in which the

45. See, e.g., The Employment Appeal Tribunal's decision in Berrisford v. Woodward Schools (Midland Division) Ltd. [1991] I.R.L.R. 247. The Employment Appeal Tribunal apparently took account of the employer's motive in dismissing a pregnant employee when coming to its finding that there had been no direct discrimination. The House of Lords has, however, made it plain (fames v. Eastleigh Borough Council [1990] I.R.L.R., 288) that motive is irrelevant in relation to direct discrimination. 
legislation has been interpreted ${ }^{46}$ and, more importantly, by the provision in the legislation which allows a practice which undeniably has an adverse impact on women to be justified, for example, on the grounds that it is economically necessary. The very fact that this can happen means that a condition that works to men's advantage will remain in place. In such cases the standard to which women have to aspire will remain a male standard.

The Equal Pay Act also appears to work to men's benefit. To derive assistance from the legislation a woman has to demonstrate that she is undertaking work that can be considered the equivalent of that undertaken by a higher paid male colleague in the same employment. The job segregation that is such a feature of women's employment may mean that this is an impossible task. Even if a woman can point to a male comparator, the employer can then try to justify the discrepancy in pay on grounds other than those of sex.

There are those who dispute the claim that the concepts of direct and indirect discrimination work only to the advantage of women who can adopt a male lifestyle.

To quote Rubenstein again:

"To dismiss equality of opportunity merely as 'formal' equality, of benefit only to those women similarly situated to men, is far too negative a conception of disparate treatment theory. The fundamental direct discrimination principle is that gender (or race) may not be used as a criterion or ground for an employment decision." 47

The problem with this statement is that since the pattern of many women's lives is so very different from those of men they will never find themselves in a position where the anti-discrimination legislation can be of use. Even if its aim is to stop gender being used as the basis for an employment decision, and there may be doubts over whether the courts actually apply the law in this manner, many women are never in the fortunate situation where they have the same opportunities as men. Where they do have those opportunities all the evidence seems to point to the process of discrimination continuing unchecked.

Women obviously face a dilemma in determining the legislative strategy which will best secure them equality. ${ }^{48}$ Should they demand to be treated in exactly the same manner as men or should they expect the law to acknowledge the differences

46. E.g., the manner in which the court determines whether a considerably smaller number of women as opposed to men can comply with the condition. A full analysis of how the court has applied the concept of indirect discrimination can be found in Morris and Nott, supra n. 7, Chapter 5 and E. Ellis, Sex Discrimination Law (Gower, 1988).

47. Rubenstein, supra n. 1, p. 262.

48. In her essay "Difference and Dominance: On Sex Discrimination" in Feminism Unmodified (Harvard Univ. Press, 1987), p. 32, Catherine MacKinnon explores the thinking that underlies sex equality law. 
between the sexes, as already happens in relation to pregnancy? ${ }^{29}$ The problem is that the more women demand that the law should take account of differences the more that is seen as undermining women's claim for equal treatment. In other words, how can equal treatment demand different treatment? Viewed in this light the anti-discrimination legislation is bound to be less than a whole-hearted success since by espousing the concept of equal treatment it fails to address the differences which exist between the sexes. Indeed, a concept of equality which is based on equal treatment may in reality do women more harm than good. As a matter of history situations have arisen where women have been treated more favourably than men. They are few in number but undoubtedly they do exist. The most familiar of these relates to the age when an individual becomes entitled to their retirement pension. Within the United Kingdom a woman may be entitled to a pension, and hence to retire, when she reaches her sixtieth birthday but a man may have to wait until he is sixty-five. After a series of cases it has been settled that to have one age (commonly sixty) at which women retire and draw their pensions and another (commonly sixty-five) for men can be discriminatory. ${ }^{50}$ The practical consequences of these decisions has been the equalising of pensionable and retirement ages for men and women. In many cases that process of equalisation has ended with women being treated in the same manner as men. In other words, this has been a situation where men have not secured the favourable treatment previously accorded women but have ensured that women no longer enjoy this advantage.

Indeed the notion that equality requires that men and women be treated in the same fashion has permeated beyond the public sphere of the workplace. Rightly or wrongly, it was generally accepted that the welfare of any child might best be served by granting custody to its mother, with its father being allowed reasonable access, after its parents had divorced. That practice has now been abandoned in favour of granting custody to both parents on the basis that it is in the best interests of any child to maintain contact with both its parents after a divorce. Leaving aside the psychology of what best suits a child, many commentators feel that the notion of equal treatment and equal rights has been exploited by men in order to advance their case. In so doing the role of the primary caregiver, who is normally the child's mother, is ignored in resolving the issue of custody..$^{51}$ This is yet another instance of how the language of equality can be used to women's disadvantage.

49. Employment Protection (Consolidation) Act 1978, sections 31A, 45 and 60.

50. Marshall v. Southampton and South-West Hampshire Area Health Authority (Teaching), 152/84 [1986] I.C.R. 335. Marshall determined that to force a woman to retire at 60 when a man need not retire until he was 65 was in breach of the Equal Treatment Directive and hence discriminatory. See now section 3, Sex Discrimination Act 1986. Barber v. Guardian Royal Exchange Assurance Group [1990] I.R.L.R. 240 determined that refusing a man an occupational pension when a woman of the same age would be paid a pension was discriminatory. The benefits represented by a contracted out occupational pension constituted 'pay' within the terms of Article I19 which requires that men and women should receive equal pay for equal work.

51. Smart, supra n. 5, pp. 153-157. 
If it is correct to argue that the current anti-discrimination legislation does not secure equal opportunities for women then the best solution would simply seem to be to remodel the legislation. The law could be amended to better serve the needs of women if it assessed their treatment from the perspective of whether the behaviour in question had an adverse impact on women. The fact that men were treated in the same manner or that the practice was said to have an economic justification would be irrelevant. Legislation along such lines appears unlikely. It would provoke charges that it amounted to positive discrimination in favour of women and discriminated against men. The term 'positive discrimination' has always been anathema in the United Kingdom with its underlying implication that an individual is being given access to a benefit that somehow they do not deserve. To treat women in a certain manner simply because they are women and not because of need or merit is regarded as unjust. ${ }^{52}$ The counter-argument that men have benefited from positive discrimination for centuries, since it is the male standard which is adopted as the norm, is met with disbelief or the response that two wrongs do not make a right.

There are those who, faced with the equality/difference argument over antidiscrimination legislation, argue that it is women's subordination to men which explains their lack of progress and that until this subordination is exposed women can hope for little from the law. In short, "an equality question is a question of the distribution of power." ${ }^{53}$ To tackle inequality it is not sufficient to try to construct laws that accept the existing imbalance of power. Instead, the real root of the problem has to be tackled. A writer such as Catherine MacKinnon who adopts this particular approach dismisses any attempt to "make rules that fit reality". Instead she urges criticism of reality and exposure of "that which women have had little choice to be confined to, in order to change it." 54 That reality includes not only poor pay or the poverty that women experience in old age but also the sytematic abuse that women endure in the shape of domestic violence, rape and pornography. The very fact that women are treated as objects and that their sexuality is regarded as a legitimate means of generating wealth is evidence of the low esteem in which women are held and their lack of power. In short, power belongs to men and as a consequence men have been able to shape the law and the entire legal system in order to reflect their standards. To quote Catherine MacKinnon once again, the "law sees and treats women the way men see and treat women." 55 So the problem is not simply to secure better anti-discrimination legislation but to bring about fundamental changes in the entire legal system and society in general so that they cease to reflect the standards of one particular sex.

52. J. Edwards, Positive Discrimination (Tavistock, 1987).

53. C. MacKinnon, "Difference and Dominance: On Sex Discrimination", Feminism Unmodified (Harvard Univ. Press, 1987), p. 40.

54. Ibid., p. 40.

55. C. MacKinnon, "Feminism, Marxism, Method, and the State: Towards a Feminist Jurisprudence", Signs, 1983, p. 644. 
Undoubtedly this represents a radical explanation for the law's failure to improve the situation of women in society. Discrimination is seen as a process that can extend to every aspect of life and is not confined to those situations specifically referred to in the anti-discrimination legislation, such as the workplace or the education system. Whole areas of law, such as those relating to crime or property rights require re-examination in order to deduce whether they do indeed embody male standards. Nor should this review be confined to the law's content. The whole mechanism of legal administration may also work to men's advantage. For example, the law's use of the adversarial system whereby each party presents their version of the truth using only those facts that the law considers relevant may work to women's detriment. As one commentator has pointed out: "[W] hat the judge decides is the truth of the matter is not only a function of the persuasive skills of the advocate but is also a product of the judge's own experience of 'reality'." ${ }_{56}$ As a consequence, the law's much emphasised objectivity may be no more than a "powerful political tool which has served to disguise what feminists have shown to be the often sexist assumptions implicit in the workings of the law." 57

Many writers associate themselves with this condemnation of the law as reflecting male values. Whilst it may provide the key to women's lack of progress it poses a dilemma as to how women should proceed so as to gain the equality that has eluded them. On the one hand, there are those, such as Catherine MacKinnon, who seem convinced that, for all its imperfections, it is still possible for women to resort to the law. Presumably by identifying the true problem women are thereby equipped to demand laws that will truly serve their purposes and will not be deflected by arguments that what they require is unjust. Instead, they will be able to counter any such claim with the response that the eradication of male domination is not something over which one should argue.

Other writers, however, having conceded the law's power to represent itself as embodying an objective truth and to oppress women, do not accept that it is to the law that women must turn in order to secure change. Carol Smart, for example, criticises Catherine MacKinnon for placing so much faith in the law:

"I agree with MacKinnon that law is powerful in silencing the alternative discourse of women, but I see it as far less powerful in transforming society to meet the various needs of all women." 58

Instead, Smart urges women to resort to non-legal strategies rather than law reform. Changes to the law can be taken away or can be interpreted out of existence. What is important is for women to be aware of the law's power to ignore their opinions and to represent itself as objective. Once this has been

56. N. Naffine, Law and the Sexes (Allen and Unwin, 1990), p. 46.

57. Ibid., p. 47.

58. Smart, supra n. 5, p. 81. 
acknowledged then women will recognise the futility of expecting the law to offer a solution to their problems.

There are some women, however, who concede that it is unrealistic to claim that the law always works to men's advantage.$^{59}$ This view of the law combines feminist as well as socialist elements. Whilst conceding the law's masculinity, the point is made that not all men benefit equally from the law. Only those men who fit a certain stereotype can extract the maximum benefit. Any woman who can fit this stereotype can just as easily take advantage of the legal system. Judged on this basis, the law favours a particular class as well as a particular sex. The law is not seen as being so systematic in its approach that it is consistently capable of favouring one sex over another. Other factors such as wealth and the possession of property are seen as influencing the law. Hence if a woman owns property, though admittedly far fewer women than men do so, the law will protect her interests in preference to a non-property owning man.

Faced with these numerous explanations of why the law has failed women, it is impossible to state categorically that one rather than another represents the truth. What they all have in common, however, is the notion that the legal system, as it currently exists, is imbued with male (and perhaps middle-class) values. Perhaps this is the nearest one can come to offering a solution to the conundrum of the law's treatment of women. That solution demands a vigorous reappraisal of the values which underpin our legal system and the manner in which it is administered. 